\title{
Dinophysis Species Associated with Diarrhetic Shellfish Poisoning Episodes in North Patagonian Gulfs (Chubut, Argentina)
}

\author{
Author(s): Leiéen Gracia Villalobos, Norma Santinelli, Viviana Sastre, Bernd Krock and José Luis
} Esteves

Source: Journal of Shellfish Research, 34(3):1141-1149.

Published By: National Shellfisheries Association

DOI: http://dx.doi.org/10.2983/035.034.0339

URL: http://www.bioone.org/doi/full/10.2983/035.034.0339

BioOne (www.bioone.org) is a nonprofit, online aggregation of core research in the biological, ecological, and environmental sciences. BioOne provides a sustainable online platform for over 170 journals and books published by nonprofit societies, associations, museums, institutions, and presses.

Your use of this PDF, the BioOne Web site, and all posted and associated content indicates your acceptance of BioOne's Terms of Use, available at www.bioone.org/page/terms of use.

Usage of BioOne content is strictly limited to personal, educational, and non-commercial use. Commercial inquiries or rights and permissions requests should be directed to the individual publisher as copyright holder. 


\title{
DINOPHYSIS SPECIES ASSOCIATED WITH DIARRHETIC SHELLFISH POISONING EPISODES IN NORTH PATAGONIAN GULFS (CHUBUT, ARGENTINA)
}

\author{
LEILÉN GRACIA VILLALOBOS, ${ }^{1 *}$ NORMA SANTINELLI, ${ }^{2}$ VIVIANA SASTRE, ${ }^{2}$ \\ BERND KROCK ${ }^{3}$ AND JOSÉ LUIS ESTEVES ${ }^{1}$ \\ ${ }^{1}$ Centro Nacional Patagónico (CONICET), Boulevard Brown 2915, 9120 Puerto Madryn, Chubut, \\ Argentina; ${ }^{2}$ Facultad de Ciencias Naturales, Universidad Nacional de la Patagonia "San Juan Bosco", \\ Julio Argentino Roca $1151^{\circ}$ piso, 9100 Trelew, Chubut, Argentina; ${ }^{3}$ Alfred Wegener Institut-Helmholtz \\ Zentrum für Polar- und Meeresforschung, Chemische Ökologie, Am Handelshafen 12, 27570 \\ Bremerhaven, Germany
}

\begin{abstract}
The marine dinoflagellate genus Dinophysis Ehrenberg is globally distributed in coastal and oceanic waters and can produce lipophilic toxins. These toxins can accumulate in filter-feeding shellfish and cause diarrhetic shellfish poisoning (DSP). Between 2009 and 2011 the two most frequent and abundant Dinophysis species found in North Patagonian gulfs were Dinophysis tripos Gourret and Dinophysis acuminata Claparède and Lachmann, and in 2015 D. tripos was the only toxic species found in moderate to high relative abundances when mouse bioassay results for DSP were positive. The positive results from mouse bioassay for DSP agree with moderate to high relative abundances of $D$. tripos and it was the only potentially toxic Dinophysis species found in the samples. The toxin profiles consisted mainly of pectentoxin-2 (PTX-2) followed by PTX-11 and PTX-2 seco acid. The toxin profiles of the samples could be associated with D. tripos, because the maximum proportion of D. acuminata did not exceed $1.3 \%$ of total Dinophysis cells in any of the samples. The results suggest that shellfish accumulated high levels of PTX when D. tripos was at a high abundance. To our knowledge, this is the first record of positive results in the mouse bioassay for DSP related to D. tripos and with closures of shellfish harvesting in North Patagonian gulfs.
\end{abstract}

KEY WORDS: Dinophysis tripos, Dinophysis acuminata, diarrhetic shellish poisoning, mouse bioassay, liquid chromatographytandem mass spectrometry, North Patagonian gulfs

\section{INTRODUCTION}

Diarrhetic shellfish poisoning (DSP) is a specific type of food poisoning and a severe gastrointestinal illness caused by the ingestion of filter-feeding bivalves contaminated with a specific suite of marine toxins (Yasumoto et al. 1984, Domínguez et al. 2010). Diarrhetic shellfish poisoning is globally reported with recurring cases in Europe, South America, and Southeast Asia (Hallegraeff 1993, Van Dolah 2000, Reguera et al. 2012). The most characteristic symptoms of DSP intoxication are diarrhea, nausea, vomiting, abdominal pain, and chill. No human fatalities attributed to DSP have been reported; however, some of the DSP toxins may promote stomach tumors and thus cause chronic problems in shellfish consumers (Suganuma et al. 1988, Larsen \& Moestrup 1992). Three chemically different lipophilic groups of toxins have been historically associated with DSP: okadaic acid (OA) and dinophysistoxins (DTX), pectenotoxins (PTX), and yessotoxins (Domínguez et al. 2010). Both OA and the DTX are acid polyethers that inhibit protein phosphatases, and are the only toxins of the old "DSP complex" with diarrheogenic effects (Reguera et al. 2012). Okadaic acid and its congeners DTX-1 and DTX-2 are the main toxins responsible for the DSP syndrome (Yasumoto et al. 1985); however, PTX and yessotoxins have been considered as DSP toxins mainly because they are extracted together with OA and DTX for DSP testing (Yasumoto et al. 1985, Murata et al. 1987, Domínguez et al. 2010). The PTX are polyether-lactones, some of which are hepatotoxic to mice by intraperitoneal injection. The PTX-2 and its shellfish-mediated derivative, PTX-2 seco acid (PTX-2sa), are not toxic to mice when administered orally and

*Corresponding author. E-mail: gracia@cenpat.edu.ar DOI: $10.2983 / 035.034 .0339$ their potential threat to human health is currently under debate (Miles et al. 2004, Reguera et al. 2012). Yessotoxins are disulfated polycyclic polyether toxins and are toxic to mice only by intraperitoneal injection (Aune et al. 2002, Tubaro et al. 2003).

Okadaic acid and DTX are mainly produced by planktonic dinoflagellates of the genus Dinophysis and Prorocentrum lima Ehrenberg (Dodge) (Gayoso et al. 2002, Maranda et al. 2007). To date, 12 species of Dinophysis have been reported to contain lipophilic toxins (Yasumoto et al. 1985, Reguera \& Pizarro 2008, Rodríguez et al. 2012). Of these species, seven (Dinophysis acuminata, Dinophysis acuta Ehrenberg, Dinophysis caudata Saville-Kent, Dinophysis fortii Pavillard, Dinophysis miles Cleve, Dinophysis ovum Schütt, Dinophysis sacculus Stein) have been associated with DSP events (Reguera et al. 2012). In New Zealand, Chile, and along the Atlantic coasts of Europe, Dinophysis acuminata and D. acuta have been reported as the main causative agents of lipophilic shellfish toxin events in shellfish above regulatory levels (van Egmond et al. 1993, Raho et al. 2008, Reguera \& Pizarro 2008). Previously, many questions about the ecology, behavior, toxin content, and genetic diversity of Dinophysis populations remained unanswered. This is partly due to the fact that researchers were unable to successfully establish laboratory cultures of Dinophysis species for many years. This obstacle was overcome when Park et al. (2006) successfully cultured an isolate of D. acuminata by providing the ciliate prey Mesodinium rubrum (Lohmann) Hamburger and Buddenbrock which in turn was allowed to feed on the cryptophyte Teleaulax sp. As a result of this culturing achievement, D. fortii (Nagai et al. 2008), D. caudata (Nishitani et al. 2008a), D. acuta (Jaén et al. 2009) and Dinophysis infundibulus Schiller (Nishitani et al. 2008b) have also been successfully cultured. Later, Rodríguez et al. (2012) 
described morphological, toxicological and genetic characteristics of $D$. tripos from cultures fed with the ciliate Mesodinium rubrum. This was the first report of the presence of PTX-2 in $D$. tripos and of the establishment of cultures of this species.

The first record of potential DSP producers along the Patagonian coast dates back to 1980. Gil et al. (1989) reported the occurrence of Dinophysis acuminata and Dinophysis fortii in the San José Gulf, being the first report of DSP producers from Chubut Province, northern Patagonia, Argentina. One year after D. acuminata was reported from the Chubut River Estuary (Sastre et al. 1990) and D. acuminata and Prorocentrum lima were recorded in phytoplankton samples from the San José Gulf and Nuevo Gulf (Santinelli et al. 1994, Santinelli et al. 2002). Later the occurrence of $D$. acuminata in Nuevo Gulf was also recorded in December 1993 and November 1994 (Santinelli 2008).

Even though DSP producing species in this region had been observed before, it was not before 1999 that the first recognized DSP outbreak reported by Gayoso and Ciocco (2001) and Gayoso et al. (2002). At a celebration, more than 40 people suffered from gastrointestinal disorders after consuming shellfish, with diarrhea, nausea, and vomiting. This episode coincided with the presence of the epibenthic Prorocentrum lima in the stomach content of mussels Aulacomya atra Molina and Mytilus edulis platensis d'Orbigny and in water samples from San José and Nuevo Gulfs. Eleven years later, Sar et al. (2010) detected the toxigenic Dinophysis species Dinophysis acuminata and Dinophysis caudata and lipophilic shellfish toxins in two bivalve species from the coast of Buenos Aires Province. This was the first record of detection of an outbreak of DSP associated with the presence of Dinophysis species in Argentina. Most recently, another PTX producing species, Dinophysis tripos, was reported for the Argentine Sea (Fabro et al. 2015). Previous work was further supplemented by the survey carried out by Sar et al. (2012), which focused on the detection of DSP toxins in shellfish samples. Their results showed that shellfish were contaminated with a DSP toxin profile composed of OA, DTX-1 and DTX-3. Besides this report, however, little nothing is known about the linkage of positive DSP mouse bioassays and the original phytoplankton toxin profiles in this area. For this reason the major aim of this study was to investigate the toxin profile of toxigenic phytoplankton present in shellfish harvesting areas during harvest closure due to DSP in the Chubut Province in the years 2009 to 2011.

\section{MATERIALS AND METHODS}

\section{Phytoplankton Monitoring Program}

Data included in the present study came from the Harmful Algal Bloom and Shellfish Toxicity Monitoring Program, carried

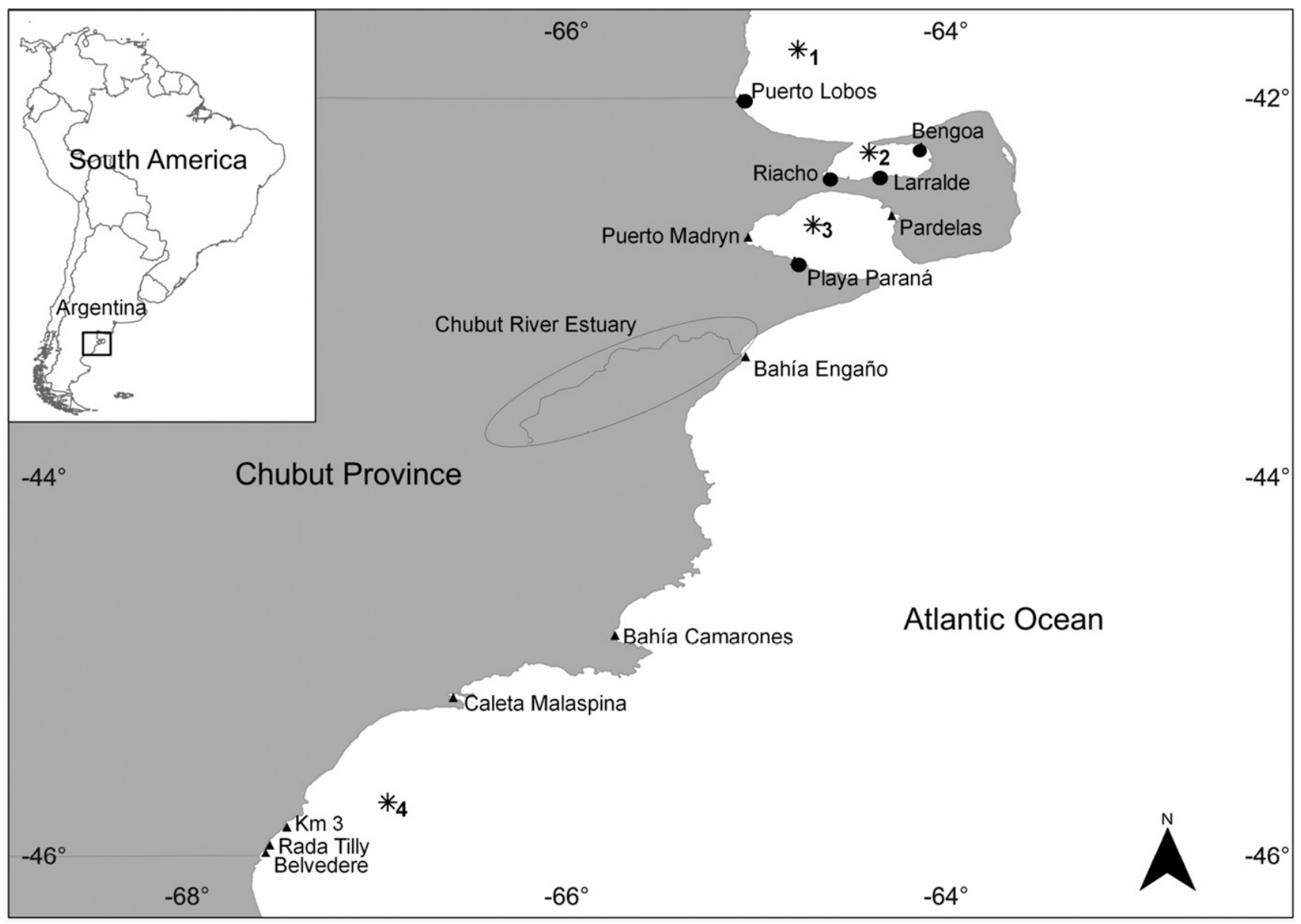

Figure 1. Map of the study area showing the sampling stations, including analyzed sites (black circles) and unanalyzed sites (black triangles). Numbers marked with an asterisk indicate the location of Patagonian gulfs: 1 = San Matías Gulf; 2 = San José Gulf; 3 = Nuevo Gulf; 4 = San Jorge Gulf. 
out through a working agreement between the Subsecretaría de Pesca, Universidad Nacional de la Patagonia "San Juan Bosco" (UNPSJB), Centro Nacional Patagónico (CENPAT), Ministerio de Ambiente, Secretaría de Turismo y Áreas Protegidas and Secretaría de Salud. The monitoring program includes a total of 13 stations along the coast of Chubut that were sampled from 2000 (Fig. 1). Field sampling was carried out in the North Patagonian gulfs (between $41^{\circ}$ and $43^{\circ} \mathrm{S}$ ): San Matías, San José and Nuevo, located on the Northeastern coast of the Chubut Province, Argentina. Between 2009 and 2011 samples were collected monthly and occasionally biweekly at stations Puerto Lobos (San Matías Gulf), Bengoa, Larralde and Riacho (San José Gulf), and Playa Paraná (Nuevo Gulf) (Fig. 1).

Water samples for quantitative phytoplankton analyses, taken in the frame of the monitoring program, were collected using a tube sampler of $80 \mathrm{~cm}$ length and $11 \mathrm{~cm}$ diameter, to obtain integrated water column samples (Franks 1995). Subsamples of $250 \mathrm{ml}$ were preserved with Lugol's solution and stored for species identification and enumeration. In addition, qualitative phytoplankton samples were taken using a $25-\mu \mathrm{m}$ mesh net through oblique tows, and fixed with formaldehyde at a final concentration of $4 \%$.

A sampling survey to collect phytoplankton for toxin analysis was carried out during February 2015 in Larralde, Bengoa, Riacho, and Playa Paraná. The phytoplankton samples were collected by oblique net tows from $5 \mathrm{~m}$ depth to surface with a $25-\mu \mathrm{m}$ mesh net on a boat. Net haul samples were concentrated to $175 \mathrm{ml}$. Ten-millimeter aliquots of the captured material was preserved in Lugol's solution for microscopic observation and used to calculate the cells concentration, and the remainders of the samples were then filtered through Whatman GF/F filters and frozen $\left(-20^{\circ} \mathrm{C}\right)$ until analysis.

\section{Mouse Bioassays}

Mouse bioassays were performed at the Dirección de Salud Ambiental (Chubut Province).

The shellfish samples for analysis of DSP toxins were collected from harvested natural beds and removed from subtidal sand beds and from the substrate by underwater diving at 5-25 $\mathrm{m}$ depth. The shellfish samples were obtained from Larralde, Bengoa, Riacho, and Puerto Lobos at the same time as the phytoplankton samples. Shellfish samples were scallops (Aequipecten tehuelchus d'Orbigny), clams (Ameghinomya antique King \& Broderip), mussels (Mytilus edulis platensis) and Panopea clams (Panopea abbreviate Valenciennes), which were frozen until analysis. The mouse bioassays were performed as described by Yasumoto et al. (1984) and modified as described by Fernández et al. (2002). In brief, toxins were extracted from shellfish tissue using acetone and after evaporation the residue was dissolved in a small volume of $1 \%$ Tween 60 . The extract was injected intraperitoneally into mice with a body weight of about $20 \mathrm{~g}$ and the survival was monitored from 24 to $48 \mathrm{~h}$ according to Decision 2002/225/CEE published in the Official Journal of the European Community (EC 2002).

\section{Dinophysis Species Identification and Analyses}

All phytoplankton samples were analyzed in the Laboratorio de Hidrobiología of the Universidad Nacional de la Patagonia "San Juan Bosco".
Lugol's preserved samples were counted using the Utermöhl method (Utermöhl 1958) with a phase contrast inverted microscope (Leica DMIL). For qualitative estimation, net samples were standardized into an abundance scale. Abundance estimates were obtained by counting number of Dinophysis cells in three $0.1-\mathrm{ml}$ aliquots. The abundance classification was performed from six ranges (Table 1) according to the abundance of this species in natural populations.

A Lugol-fixed aliquot of phytoplankton samples for toxin analysis (from February 2015) was collected to determine cell density under the light microscope using a Sedgewick-Rafter chamber. Between 20 and 30 images were taken from each station using a Leica DFC450C camera mounted on a Leica DM2500 microscope at the microscopy service of the Centro Nacional Patagónico (CENPAT) - CONICET. Lengths and widths of cells were determined using Leica Application Suite (LAS) V 4.5.0 Software. Species identification was performed using the morphological criteria proposed by Balech (1988).

Further selected samples were washed in distilled water, dried under air, and coated with gold. Scanning electron microscopy observations of the samples were made with a Jeol JSM-6360 LV scanning electron microscopy at the Facultad de Ciencias Naturales y Museo, Universidad Nacional de La Plata, and with Zeiss Supra 40 at the advanced microscopy center of the Universidad de Buenos Aires (UBA).

\section{Toxin Analyses}

Filters were transferred into FastPrep vials and $700 \mu \mathrm{L}$ methanol were added. Samples were subsequently homogenized with $0.9 \mathrm{~g}$ of lysing matrix $\mathrm{D}$ by reciprocal shaking at maximum speed $(6.5 \mathrm{~m} / \mathrm{sec})$ for $45 \mathrm{sec}$ in a Bio101 FastPrep instrument (Thermo Savant, Illkirch, France). After homogenization, samples were centrifuged at $16,100 \times g$ at $4^{\circ} \mathrm{C}$ for $15 \mathrm{~min}$. The supernatant was transferred to a spin-filter $(0.45 \mu \mathrm{m}$ pore size, Millipore Ultrafree, Eschborn, Germany) and centrifuged for $30 \mathrm{sec}$ at $800 \times g$, followed by transfer to autosampler vials. Analysis of multiple lipophilic toxins was performed by liquid chromatography coupled to tandem mass spectrometry, as described in Krock et al. (2008).

\section{Statistical Analyses}

A one-way analysis of variance was used to compare cell dimensions among stations using $\mathrm{R}$ (R Core Team 2012). The extent to which the positive results for DSP were correlated with relative abundances of Dinophysis tripos was evaluated by means of a Spearman's rank order correlation matrix using $\mathrm{R}$ (R Core Team 2012).

TABLE 1.

Abundance scales of Dinophysis species from net samples.

\begin{tabular}{lcc}
\hline \hline \multicolumn{1}{c}{ Scales } & & Cells/l \\
\hline Absent & 0 & 0 \\
Very scarce & 1 & $1-10$ \\
Scarce & 2 & $10-100$ \\
Frequent & 3 & $100-1000$ \\
Abundant & 4 & $1000-10000$ \\
Very abundant & 5 & $>10000$ \\
\hline
\end{tabular}


TABLE 2.

Positive results for DSP in the mouse bioassays and Dinophysis spp. concentration according to the abundance scale (Table 1).

\begin{tabular}{lllcc}
\hline \hline Date & Stations & Shellfish & $\begin{array}{c}\text { Dinophysis } \\
\text { tripos } \\
\text { abundance }\end{array}$ & $\begin{array}{c}\text { Dinophysis } \\
\text { acuminate } \\
\text { abundance }\end{array}$ \\
\hline $6 / 24 / 2009$ & Puerto Lobos & Panopea & 3 & 0 \\
$9 / 22 / 2009$ & Larralde & Clams & 3 & 2 \\
$7 / 22 / 2010$ & Puerto Lobos & Panopea & 4 & 0 \\
$7 / 22 / 2010$ & Riacho & Scallops & 4 & 0 \\
$7 / 22 / 2010$ & Bengoa & Clams & 4 & 0 \\
$7 / 7 / 2011$ & Riacho & Clams & 3 & 0 \\
$7 / 7 / 2011$ & Riacho & Mussels & 3 & 0 \\
\hline
\end{tabular}

\section{RESULTS}

\section{Mouse Bioassays}

The positive results of the mouse bioassays are shown in Table 2 that also includes abundances of potentially toxic Dinophysis species present in the phytoplankton samples.

In 2009, a total of 121 samples were analyzed out of which 2 were found positive for DSP toxins; in 2010, 3 out of 55 samples were found positive; and in 2011,2 out of 68 samples were found positive. The abundance of Dinophysis tripos was significantly correlated with positive results of the mouse bioassays ( $R=0.23, P<0.05$ ). Despite the positive DSP results in 2009 and 2010, only in July 2011 the Subsecretaria de Pesca closed the harvest of molluscs due to DSP for the first time in Riacho.
Before then the shellfish beds had been closed for harvesting annually only due to paralytic shellfish poisoning.

The administrative prohibition of harvesting of these shellfish species in Riacho was extended for a month until the results from mouse bioassays were negative again.

\section{Relative Abundance and Cell Density of Dinophysis Species}

The results of relative abundance analyses showed that the Dinophysis species most frequently found during the study period were Dinophysis tripos and Dinophysis acuminata. In addition, Dinophysis rotundata (Phalacroma rotundatum) Claparéde and Lachmann was observed with lowest frequency at Larralde and Playa Paraná (Fig. 2B, E) and Dinophysis caudata was only observed at Puerto Lobos (Fig. 2D).

Almost the whole year, Dinophysis tripos was observed at all stations with lower frequency at Riacho and Playa Paraná. In Puerto Lobos, D. tripos had two clear abundance peaks in June and August 2010 and it was most frequently present (Fig. 2D). In autumn and winter, D. tripos was mainly present with abundances of 4 and 5 in the abundance scale (Fig. 2A, D).

The abundance of Dinophysis acuminata was very variable between years and months. They were observed most frequently at Larralde and with a lower frequency at Bengoa, Puerto Lobos, and Playa Paraná. This species was present in spring and summer mainly, with an abundance of 3 in the abundance scale (Fig. 2B) and was exceptionally abundant in Riacho in autumn 2011 (Fig. 2C).

The results of cell density analyses showed that Dinophysis tripos appeared mainly at Puerto Lobos and Bengoa, in autumn and winter. At both stations, D. tripos reached high cell density, with maximum cell concentrations of 8,400 cells/1 in Bengoa and 5,880 cells/1 in Puerto Lobos. At Riacho, D. tripos was
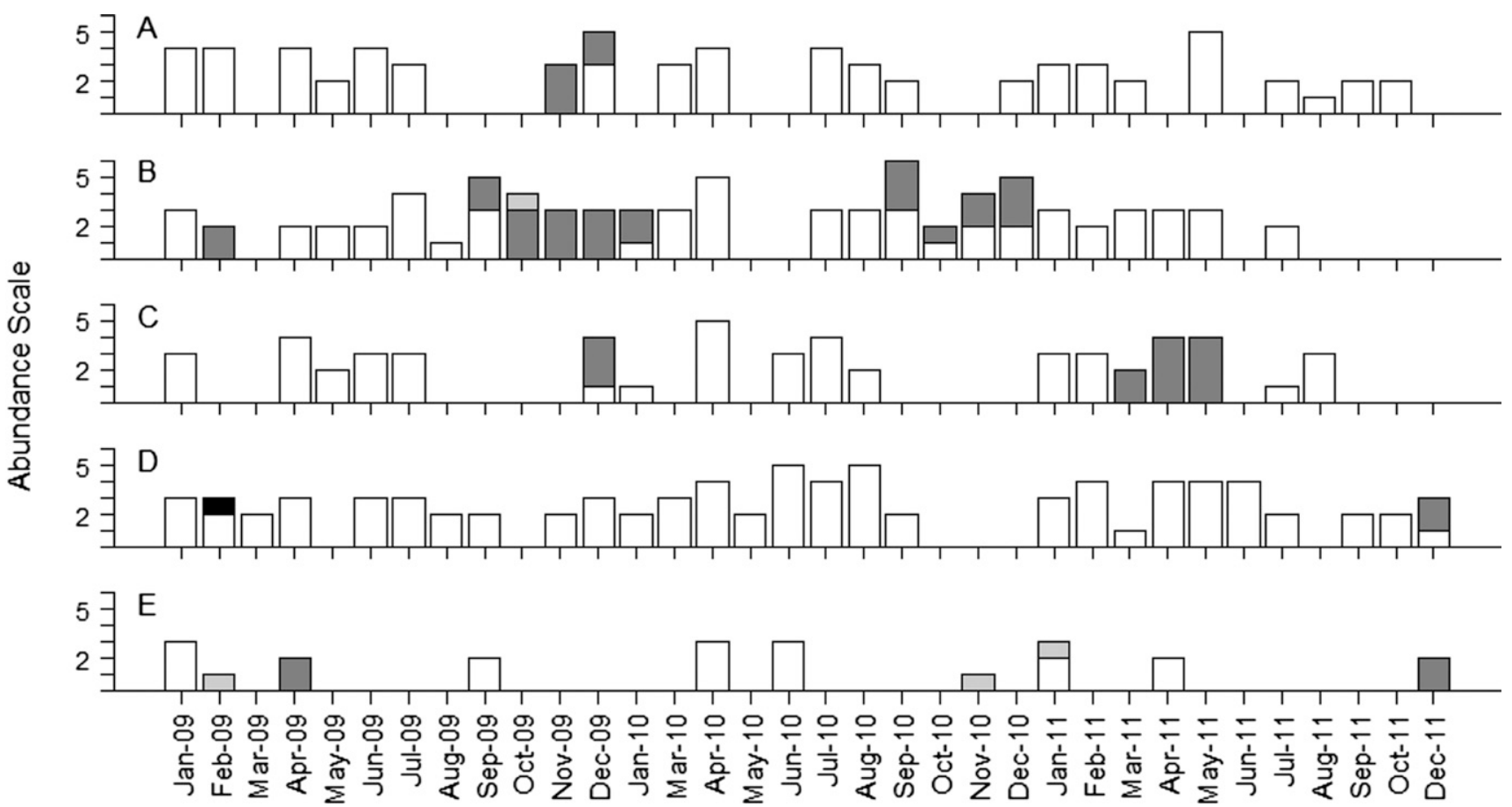

Figure 2. Relative abundance of Dinophysis tripos (white bars), Dinophysis acuminata (gray bars), Dinophysis caudata (black bars), and Dinophysis rotundata (light gray bars) recorded at stations: Bengoa (A), Larralde (B), Riacho (C), Puerto Lobos (D), and Playa Paraná (E). 
present with a high cell density of 6,720 cells/1, but was present just once (Fig. 3A).

In spring and summer, Dinophysis acuminata, however, appeared mainly at Larralde. In this station, D. acuminata reached the maximum cell concentration of 4,200 cells/l. In the remaining stations, D. acuminata was present sporadically (Fig. 3B).

\section{Morphology and Cell Dimensions of Dinophysis spp. Associated with DSP}

\section{Dinophysis tripos}

The analyzed cells of Dinophysis tripos, very distinctive species, showed morphological characteristics in agreement with the descriptions of Balech (2002) and Faust and Gulledge (2002). The cells are laterally compressed with a small, cap-like epitheca and a much larger hypotheca. The sizes of the cells are large, anterioposteriorly elongated and asymmetrical with two posterior hypothecal projections; a longer ventral process and a shorter dorsal one. Hypothecal projections with toothed posterior ends, and well-developed left sucal list widens posteriorly and reticulated. The thick thecal plates are heavily areolated (Fig. 4B).

The cells of Dinophysis tripos varied between 90 and $108 \mu \mathrm{m}$ in length and 41 and $58 \mu \mathrm{m}$ in dorsoventral depth with a length: width ratio of 1.98 . Of the four analyzed sites, Bengoa only presents significant differences in maximal length (analysis of variance, $P<0.05$; Table 3 ).

\section{Dinophysis acuminata}

The morphological traits of analyzed cells agree with the descriptions of Faust and Gulledge (2002) and Balech (2002). Cells are small and somewhat oval shaped, with a convex dorsal margin (Fig. 4D). The thick thecal plates were covered with prominent circular areolae, each with a pore. The antapex is

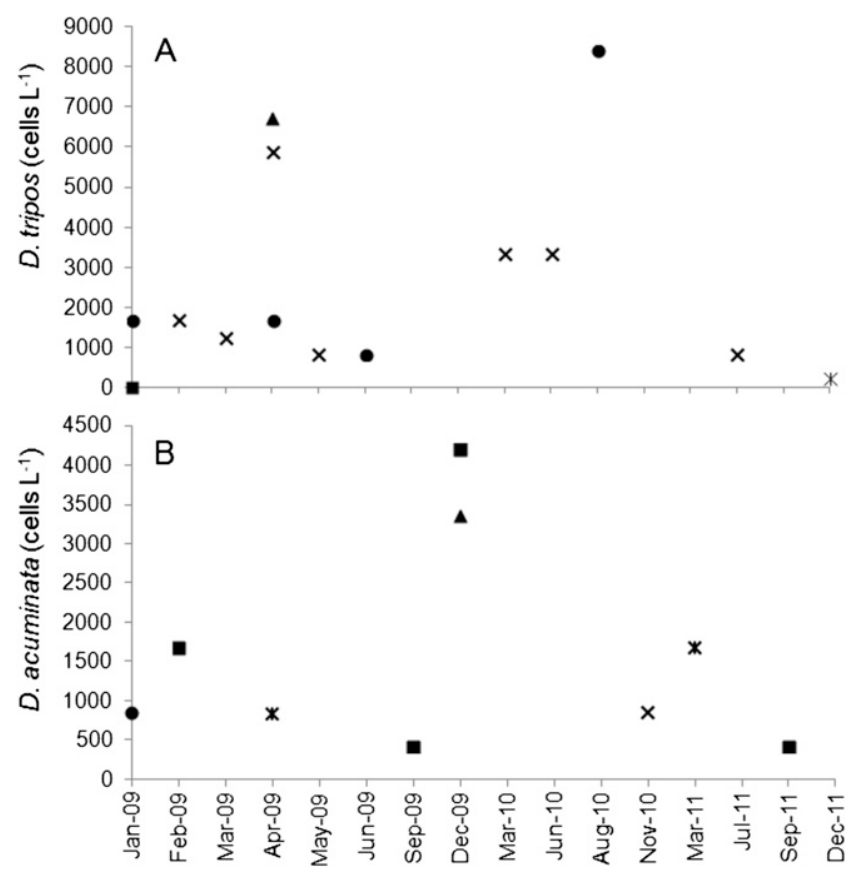

Figure 3. Cell density of Dinophysis spp. recorded at stations: Bengoa (circle), Larralde (square), Riacho (triangle), Puerto Lobos (crosses), and Playa Paraná (asterisks). (A) Dinophysis tripos, (B) Dinophysis acuminata. rounded, and cells had well developed small knob-shaped posterior protrusions (Fig. 4D).

The cell size varied between 39 and $44 \mu \mathrm{m}$ in length and 32 $37 \mu \mathrm{m}$ in dorsoventral width, and the length:width ratio was 1.2.

\section{Toxin Measurements and Species Distribution}

Qualitative plankton samples from four different locations were taken in which Dinophysis cells were enumerated and lipophilic toxins were determined. The only two Dinophysis species detected were Dinophysis tripos and Dinophysis acuminata, the latter never exceeding $1.3 \%$ of total Dinophysis cells present in the samples. The toxin profiles in all four samples were very similar consisting mainly of PTX-2 followed by PTX11 and PTX-2sa (Fig. 5). The highest amount of Dinophysis was found at Riacho, whereas the highest amount of PTX was detected at Playa Paraná. The calculated total PTX cells quotas of the Dinophysis cells in these four samples range from $1.2 \mathrm{pg}$ PTX per cell (Bengoa) to 3.8 pg PTX per cell (Larralde).

\section{DISCUSSION}

\section{Shellfish Toxicity Associated with Dinophysis spp.}

The intensification of Dinophysis tripos blooms in North Patagonian gulfs occurred in parallel with the confirmed presence of DSP toxins in shellfish. In July 2011, mussel and clam beds in Riacho were closed for harvesting due to positive results for DSP in the mouse bioassays, being the first shellfish harvesting closure due to the DSP toxins in the San José Gulf.

Mouse bioassays for DSP toxins gave positive results for San José and San Matías gulfs mainly in the austral autumn and winter months. Only one positive result was registered in spring. High abundances of Dinophysis tripos were registered usually in close temporal and spatial proximity to shellfish samples that contained DSP toxins. Only in one of these plankton samples in addition to D. tripos, low abundance of Dinophysis acuminata (less than $1.5 \%$ of total Dinophysis) was detected so that all positive results for DSP correlate with moderate to high relative abundances of $D$. tripos (Table 2). Thus, our data suggest that $D$. tripos was clearly associated with this DSP event. These results also suggest that high levels of DSP toxins in shellfish occur when D. tripos is highly abundant. This finding contradicts the report of Reguera et al. (2012) that mentions the absence of reports of DSP outbreaks associated with $D$. tripos or cases in which this species would have been the only potentially toxic Dinophysis species present in the microplankton community (Caroppo et al. 1999, Pazos et al. 2010). Our findings, however, strongly support the results of Fabro et al. (2015) who recorded the association between $D$. tripos and pectenotoxins in Argentine Sea. The cooccurrence of Dinophysis species and DSP toxins highlight the need of additional field studies as well as culture establishment to unambiguously elucidate the toxin profiles of $D$. tripos and D. acuminata in the South West Atlantic.

\section{Distribution and Abundances of Dinophysis spp.}

The species Dinophysis tripos has been reported to be widely distributed in tropical and warm-temperate waters, and occasionally found in colder areas (Larsen \& Moestrup 1992) transported by warm-water currents, such as in the Norwegian 


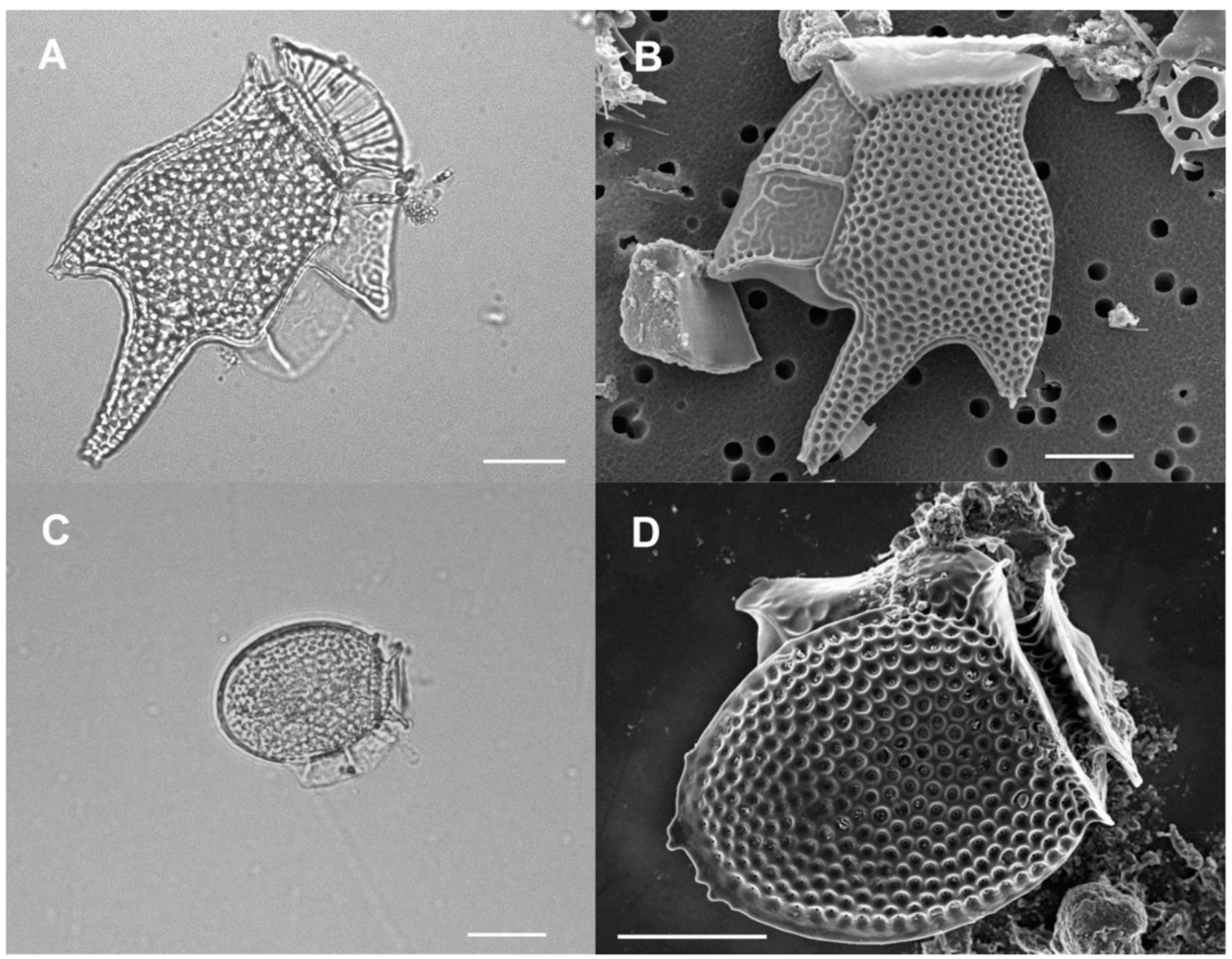

Figure 4. Light and electronic micrographs of Dinophysis species. (A) Light micrographs of Dinophysis tripos in right lateral view. (B) Electronic micrographs of D. tripos in left lateral view. (C) Light micrographs of Dinophysis acuminata in right lateral view. (D) Electronic micrographs of D. acuminata in left lateral view. Scale bars: $20 \mu \mathrm{m}$.

Sea and subantarctic waters of the South Atlantic (Johnsen \& Lømsland 2010). In the Argentine Sea, it is known to occur between $36^{\circ}$ and $55^{\circ} \mathrm{S}$ (Balech 2002). But D. tripos has never been cited as the causative agent of DSP events when it was the only or the overwhelmingly dominant species of Dinophysis in the microphytoplankton (Reguera et al. 2014). In contrast, Dinophysis acuminata has been identified as the causative agent of DSP in Southern Brazil (Proença et al. 2007) and, combined with Dinophysis caudata, in Uruguay (Méndez \& Ferrari 2002) and Argentina (Sar et al. 2010). A coastal species, D. acuminata, has a strong negative impact on shell fisheries, because it is an early blooming species with a very long growing season (spring to autumn). This is the most cosmopolitan Dinophysis species associated with DSP events (Reguera et al. 2014).

Several Dinophysis species were reported in quantitative samples between the start of the monitoring program in 2000 and the study period of this work (2009 to 2011). For example, Dinophysis acuminata was registered in San Matías, San José, Nuevo, and San Jorge gulfs, and in Bahia Engaño and Bahia Camarones being present in spring and summer mainly. In November 2007, D. acuminata reached a maximum cell density of $5 \times 10^{3}$ cells/1 in the San José Gulf. The species Dinophysis tripos has been detected in San Matías, San José, Nuevo, and San Jorge gulfs, and Bahia Engaño throughout all seasons. It was recorded for first time in May 2007 with a cell density of $2 \times 10^{3}$ cells/1 (Puerto Lobos) and reached a maximum cell density of $8 \times$ $10^{3}$ cells/l in August 2010 (Bengoa). With a highest cell density of $4 \times 10^{2}$ cells $/ 1$, Dinophysis fortii was registered in January 2006 at the Puerto Madryn City. Two species, Dinophysis rotundata

TABLE 3.

Length (L) and dorsoventral depth $(\mathrm{H})$ of the hypothecal plates of cells of Dinophysis tripos.

\begin{tabular}{lcccc}
\hline \hline & Bengoa & Larralde & Riacho & Playa Paraná \\
\hline L range & $89-105$ & $93-108$ & $95-108$ & $94-106$ \\
H range & $43-58$ & $45-55$ & $41-54$ & $45-58$ \\
L average & 97 & 101 & 100 & 100 \\
H average & 50 & 50 & 50 & 51 \\
L:H average & 1.96 & 2 & 1.91 & 1.96 \\
\hline
\end{tabular}




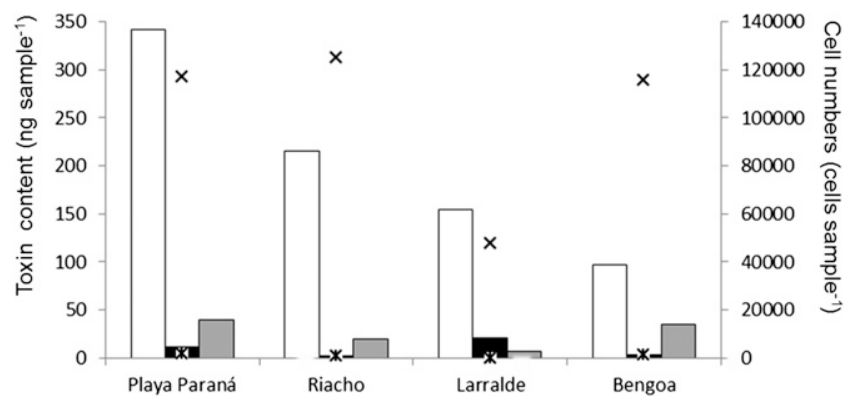

Figure 5. Cell abundances of Dinophysis acuminata (asterisks) and Dinophysis tripos (crosses) in phytoplankton samples and amount of PTX: PTX-2 (white bars), PTX-2sa (black bars), and PTX-11 (gray bars).

(Phalacroma rotundatum) and Dinophysis caudata, were not found in quantitative samples, although they were registered in qualitative samples in October 2005 (Caleta Malaspina) and February 2009 (Puerto Lobos), respectively (data unpublished).

At present, high densities of Dinophysis species are known to occur in North Patagonian gulfs. In fact, the blooms of Dinophysis tripos $\left(8 \times 10^{3}\right.$ cells $\left./ 1\right)$ and Dinophysis acuminata $\left(5 \times 10^{3}\right.$ cells $)$ mentioned above, constitute examples of the fact that they are the two most common and abundant Dinophysis species found in North Patagonian gulfs in the last decades. In addition, densities of these Dinophysis species increased from moderate to high $(>1,000$ cells/l) through the years. The other Dinophysis species we found in North Patagonian gulfs throughout our study period were Dinophysis caudata and Dinophysis rotundata, although they occurred only sporadically and in low densities (Fig. 2B-E).

Abundances of Dinophysis tripos occurring throughout the year at all analyzed stations, suggest that temperature was not an important factor in determining the seasonal distribution of this species; although, highest abundances were detected in fall and winter (Fig. 2A, C, D). In contrast, the presence of Dinophysis acuminata is restricted mostly to spring and summer months (Fig. $2 \mathrm{~A}-\mathrm{C}$ ). Abundances of $D$. acuminata were variable spatially and temporarily; however, the presence was higher at Larralde (Fig. 2B).

In the quantitative analyses high cell concentrations of Dinophysis tripos were found mainly in autumn and winter, but restricted mostly to Puerto Lobos and Bengoa (Fig. 3A). In contrast, Dinophysis acuminata was present with high cell concentrations in December, but it was infrequently at all stations (Fig. 3B). These results are in accordance with the results of relative abundance of both Dinophysis species.

These results showed that Dinophysis species only appeared sporadically in quantitative samples. There are two possible explanations for this finding: on one hand, the sporadic occurrence in quantitative plankton samples may be due to low cell densities, a common feature among Dinophysis spp., which makes it difficult to acquire accurate quantitative information and will often be associated with high counting errors (Reguera et al. 2012). On the other hand, it is known that populations of Dinophysis are aggregated in patches or in thin layers of the water column and thus may escape observation with conventional sampling methods (Escalera et al. 2012).

\section{Morphological Characterization of Dinophysis spp.}

The species identified through morphological analyses were Dinophysis tripos and Dinophysis acuminata. The length, width, and length:width ratio of the North Patagonian gulfs samples were well within the range of those reported globally for D. tripos and D. acuminata (Larsen \& Moestrup 1992) (Table 3). The morphological characteristics of Dinophysis species were in accordance with those previously described by Balech (2002) and Faust and Gulledge (2002) (Fig. 4).

The shape of the cell in lateral view is the most important criterion used for identification of Dinophysis tripos (Taylor et al. 1995); however, the size and shape varies considerably in this species (Larsen \& Moestrup 1992). Nevertheless, in the present study, cells of $D$. tripos did not exhibit the marked morphological variability as those observed by Rodríguez et al. (2012). They reported that besides the normal shape of $D$. tripos another two different forms, intermediate and small cells, are commonly observed. We found that all the analyzed cells had a dorsal projection and similar dimensions.

\section{Toxin Profiles of Dinophysis tripos from Field Samples}

In the present study, the toxin profiles of the plankton samples can be regarded to be with Dinophysis tripos, because the contribution of Dinophysis acuminata to the PTX profiles can be neglected in this case, as the maximum proportion of D. acuminata did not exceed $1.3 \%$ of total Dinophysis cells in any of the samples and no other PTX producer were present.

Fabro et al. (2015) found Dinophysis tripos to be mainly associated with PTX-2sa and to a lesser degree with PTX-2 and PTX-11, whereas our results show a clear association of D. tripos with PTX-2 and PTX-11, but we found only minor amounts of PTX-2sa in field planktonic samples. Taking into account that the samplings of Fabro et al. (2015) and of the present study took place in the same geographic region makes these results appear a contradiction. On the other hand, there are differences between both studies: Fabro et al. (2015) sampled in austral spring 2012 and fall 2013, whereas our samples originate from summer 2015. Furthermore, this study used samples from the San José and Nuevo Gulfs, whereas Fabro et al. (2015) sampled only outside theses gulfs, namely in the San Matías Gulf and along the Argentine coastline. Even though these small differences are not likely to explain different toxin profiles of the same species, it should be considered that PTX-2 and PTX-2sa are not independent compounds, but the lactone PTX-2 is easily hydrolyzed under low and high $\mathrm{pH}$ to form PTX-2sa. This is the reason why in bivalves mostly PTX-2sa is found, but hardly ever PTX-2. On the other side, in fresh planktonic samples containing Dinophysis spp. the most abundant variant normally is PTX-2. In this sense our data suggest that D. tripos in fact is a de novo producer of PTX-2, which is also consistent with the findings of Rodríguez et al. (2012). If hydrolysis of PTX-2 to PTX-2sa in D. tripos is due to factors such as environmental parameters or senescence remains to be investigated and clearly shows the need for the isolation and culture establishment of this species.

\section{CONCLUSION}

The species Dinophysis tripos could be identified as a PTXproducing species in North Patagonian gulfs, and thus most likely was responsible for positive DSP mouse bioassays in the region. 
The PTX-2 production associated with Dinophysis tripos along the Chubut coast is in accordance with recent observations in the Argentine Sea as well as in other regions. Our study suggests that $D$. tripos blooms associated with the presence of DSP toxins in shellfish are becoming a recurrent phenomenon in the North Patagonian gulfs.

\section{ACKNOWLEDGMENTS}

We would like to thank the Subsecretaría de Pesca and the Dirección de Salud Ambiental from Chubut Province for the data provided for this study and Patricia Dell'Arciprete from Centro Nacional Patagónico for graphical assistance. We also thank Urban Tillmann for revising this manuscript.

\section{LITERATURE CITED}

Aune, T., R. Sorby, T. Yasumoto, H. Ramstad \& T. Landsverk. 2002. Comparison of oral and intraperitoneal toxicity of yessotoxin towards mice. Toxicon 40:77-82.

Balech, E. 1988. Los dinoflagelados del Atlántico Sudoccidental. Publicaciones Especiales. Madrid: Instituto Español de Oceanografía. 310 pp.

Balech, E. 2002. Dinoflagelados tecados tóxicos del Cono Sur Americano. In: Sar, E. A., M. E. Ferrario \& B. Reguera, editors. Floraciones algales nocivas en el Cono Sur Americano. Madrid: Instituto Español de Oceanografía. pp. 123-144.

Caroppo, C., R. Congestri \& M. Bruno. 1999. On the presence of Phalacroma rotundatum in the Southern Adriatic Sea (Italy). Aquat. Microb. Ecol. 17:301-310.

Domínguez, H. J., B. Paz, A. H. Daranas, M. Norte, J. M. Franco \& J. J. Fernández. 2010. Dinoflagellate polyether within the yessotoxin, pectenotoxin and okadaic acid toxin groups: characterization, analysis and human health implications. Toxicon 56:191-217.

EC. 2002. Commission Decision 2002/225/EC of 15 laying down detailed rules for the implementation of Council Directive 91/492/ EEC as regards the maximum levels and the methods of analysis of certain marine biotoxins in bivalve molluscs, echinoderms, tunicates and marine gastropods. Off. J. Eur. Commun. 45: 62 pp.

Escalera, L., Y. Pazos, M. D. Doval \& B. Reguera. 2012. A comparison of integrated and discrete depth sampling for monitoring Dinophysis. Mar. Pollut. Bull. 64:106-113.

Fabro, E., G. O. Almandoz, M. E. Ferrario, M. S. Hoffmeyer, R. E. Pettigrosso, R. Uibrig \& B. Krock. 2015. Co-occurrence of Dinophysis tripos and pectenotoxins in Argentinean shelf waters. Harmful Algae 42:25-33.

Faust, M. A. \& R. A. Gulledge. 2002. Identifying harmful marine dinoflagellates. Contr. U.S. Natl. Herb. 42:1-144.

Fernández, M. L., A. Míguez, E. Cacho, A. Martínez, J. Diogéne \& T. Yasumoto. 2002. Bioensayos con mamíferos y ensayos bioquímicos y celulares para la detección de ficotoxinas. In: Sar, E. A., M. E. Ferrario \& B. Reguera, editors. Floraciones algales nocivas en el Cono Sur Americano. Madrid: Instituto Español de Oceanografía. pp. 77-120.

Franks, P. J. S. 1995. Sampling techniques and strategies for coastal phytoplankton blooms. In: Hallegraeff, G. M., D. M. Anderson \& A. D. Cembella, editors. Manual on harmful marine microalgae. UNESCO, IOC Manuals and Guides no. 33, Paris: UNESCO. pp. 25-43.

Gayoso, A. M. \& N. Ciocco. 2001. Observations on Prorocentrum lima from North- Patagonian coastal waters (Argentina) associated with a human diarrhoeic disease episode. Harmful Algae News 22:4.

Gayoso, A. M., S. Dover, S. Morton, M. Busman, P. Moeller, V. K. Fulco \& L. Maranda. 2002. Diarrhetic shellfish poisoning associated with Prorocentrum lima (Dinophyceae) in Patagonian Gulfs (Argentina). J. Shellfish Res. 21:461-463.

Gil, M. N., V. Sastre, N. Santinelli \& J. L. Esteves. 1989. Metal content in seston from the San José Gulf, Patagonia, Argentina. Bull. Environ. Contam. Toxicol. 43:337-341.

Hallegraeff, G. M. 1993. A review of harmful algal blooms and their apparent global increase. Phycologia 32:79-99.
Jaén, D., L. Mamán, R. Domínguez \& E. Martín. 2009. First report of Dinophysis acuta in culture. Harmful Algae News 39:1-2.

Johnsen, T. M. \& E. R. Lømsland. 2010. Observations of Dinophysis tripos in Norwegian coastal waters. In: Pagou, P. \& G. M. Hallegraeff, editors. Book of Abstracts and Programme, $14^{\text {th }}$ International Conference on Harmful Algae, Hersonissos-Crete, Greece. 138 pp.

Krock, B., U. Tillmann, U. John \& A. D. Cembella. 2008. LC-MS-MS aboard ship: tandem mass spectrometry in the search for phycotoxins and novel toxigenic plankton from the North Sea. Anal. Bioanal. Chem. 392:797-803.

Larsen, J. \& Ø. Moestrup. 1992. Potentially toxic phytoplankton 2. Genus Dinophysis (Dinophyceae). In: J. A. Lindley, editor. ICES identification leaflets for plankton. Copenhagen: ICES. pp. 1-12.

Maranda, L., S. Corwin, S. Dover \& S. L. Morton. 2007. Prorocentrum lima (Dinophyceae) in northeastern USA coastal waters. II: Toxin load in the epibiota and in shellfish. Harmful Algae 6:632-641.

Méndez, S. \& G. Ferrari. 2002. Floraciones algales nocivas en Uruguay: Antecedentes, proyectos en curso y revisión de resultados. In: Sar, E. A., M. E. Ferrario \& B. Reguera, editors. Floraciones algales nocivas en el Cono Sur Americano. Madrid: Instituto Español de Oceanografía. pp. 271-288.

Miles, C. O., A. L. Wilkins, R. Munday, M. H. Dines, A. D. Hawkes, L. R. Briggs, M. Sandvik, D. J. Jensen, J. M. Cooney, P. T. Holland, M. A. Quilliam, A. L. MacKenzie \& V. Beuzenberg. 2004. Isolation of pectenotoxin-2 from Dinophysis acuta and its conversion to pectenotoxin-2 seco acid, and preliminary assessment of their acute toxicities. Toxicon 43:1-9.

Murata, M., M. Kumagai, J. S. Lee \& T. Yasumoto. 1987. Isolation and structure of yessotoxin, a novel polyether compound implicated in diarrhetic shellfish poisoning. Tetrahedron Lett. 28:5869-5872.

Nagai, S., G. Nitshitani, Y. Tomaru, S. Sakiyama \& T. Kamiyama. 2008. Predation by the toxic dinoflagellate Dinophysis fortii on the ciliate Myrionecta rubra and observation of sequestration of ciliate chloroplasts. J. Phycol. 44:909-922.

Nishitani, G., S. Nagai, S. Sakiyama \& T. Kamiyama. 2008a. Successful cultivation of the toxic dinoflagellate Dinophysis caudata (Dinophyceae). Plankton Benthos Res. 3:78-85.

Nishitani, G., S. Nagai, Y. Takano, S. Sakiyama, K. Baba \& T. Kamiyama. 2008b. Growth characteristics and phylogenetic analysis of the marine dinoflagellate Dinophysis infundibulus (Dinophyceae). Aquat. Microb. Ecol. 52:209-221.

Park, M. G., K. Sunju, H. S. Kim, G. Myung, Y. G. Kang \& W. Yih. 2006. First successful culture of the marine dinoflagellate Dinophysis acuminata. Aquat. Microb. Ecol. 45:101-106.

Pazos, Y., F. Arévalo, J. Correa \& E. D. Barton. 2010. An unusual assemblage of Gymnodinium catenatum and Dinophysis in the Spanish Galician rías in 2009. In: Pagou, P. \& G. M. Hallegraeff, editors. Book of Abstracts and Programme. $14^{\text {th }}$ International Conference on Harmful Algae, Hersonissos-Crete, Greece. 47 pp.

Proença, L. A. O., M. A. Schramm, M. S. Tamanaha \& T. P. Alves. 2007. Diarrhoetic shellfish poisoning (DSP) outbreak in subtropical southwest Atlantic. Harmful Algae News 33:19-20. 
R Core Team. 2012. R: a language and environment for statistical computing., Vienna, Austria: R Foundation for Statistical Computing. ISBN 3-900051-07-0. Available at: http://www.R-project.org/.

Raho, N., G. Pizarro, L. Escalera, B. Reguera \& I. Marín. 2008. Morphology, toxin composition and molecular analysis of Dinophysis ovum Schütt, a dinoflagellate of the Dinophysis acuminata complex. Harmful Algae 7:839-848.

Reguera, B. \& G. Pizarro. 2008. Planktonic dinoflagellates which produce polyether toxins of the old DSP Complex. In: L. M. Botana, editor. Seafood and freshwater toxins: pharmacology, physiology and detection, $2^{\text {nd }}$ edition. London: CRC Press. pp. 257-284.

Reguera, B., L. Velo-Suárez, R. Raine \& M. G. Park. 2012. Harmful Dinophysis species: a review. Harmful Algae 14:87-106.

Reguera, B., P. Riobó, F. Rodríguez, P. A. Díaz, G. Pizarro, B. Paz, J. M. Franco \& J. Blanco. 2014. Dinophysis toxins: causative organisms, distribution and fate in shellfish. Mar. Drugs 12:394-461.

Rodríguez, F., L. Escalera, B. Reguera, P. Rial, P. Riobó \& T. J. Silva. 2012. Morphological variability, toxicology and genetics of the dinoflagellate Dinophysis tripos (Dinophysiaceae, Dinophysiales). Harmful Algae 13:26-33.

Santinelli, N., V. Sastre \& S. Otaño. 1994. Monitoreo de fitoplancton tóxico y toxicidad en moluscos en el litoral de la provincia del Chubut (Patagonia, Argentina). Informes de reuniones de trabajo $\mathrm{N}^{\circ}$ 101. COI-Taller Regional de Planificación Científica sobre Floraciones Algales Nocivas. Montevideo. Anexo III:6-9.

Santinelli, N., V. Sastre \& J. L. Esteves. 2002. Episodios de algas nocivas en la Patagonia Argentina. In: E. A. Sar, M. E. Ferrario \& B. Reguera, editors. Floraciones algales nocivas en el Cono Sur Americano. Madrid: Instituto Español de Oceanografía. pp. 197-208.

Santinelli, N. 2008. Fitoplancton de un ambiente costero sometido a perturbación antrópica: Bahía Nueva, Provincia del Chubut. Facultad de Ciencias Naturales Sede Trelew. Chubut, Argentina: Universidad Nacional de la Patagonia "San Juan Bosco". 176 pp.

Sar, E. A., I. Sunesen, A. Lavigne \& A. Goya. 2010. Dinophysis spp. asociadas a detección de toxinas diarreicas (DSTs) en moluscos y a intoxicación diarreica en humanos (Provincia de Buenos Aires, Argentina). Rev. Biol. Mar. Oceanogr. 45:451-460.
Sar, E. A., I. Sunsen, A. B. Goya, A. S. Lavigne, E. Tapias, C. García \& N. Lagos. 2012. First report of diarrheic shellfish toxins in mollusks from Buenos Aires Province (Argentina) associated with Dinophysis spp.: evidence of okadaic acid, dinophysis toxin-1 and their acyl derivatives. Bol. Soc. Argent. Bot. 47:5-14.

Sastre, V., N. Santinelli \& G. Caille. 1990. Diatomeas y Dinoflagelados del Estuario del río Chubut (Patagonia, Argentina). II Estructura de las Comunidades. Rev. Fac. de Ocean., Pesq. y Cs. Alimentarias. 2:181-192.

Suganuma, M., H. Fujiki, H. Suguri, S. Yoshizawa, M. Hirota, M. Nakayasu, M. Ojika, K. Wakamatsu, K. Yamada \& T. Sugimura. 1988. Okadaic acid: an additional non-phorbol-12-tetradecanoate13-acetate-type tumor promoter. Proc. Natl. Acad. Sci. USA 85:1768-1771.

Taylor, F. J. R., Y. Fukuyo \& J. Larsen. 1995. Taxonomy of harmful dinoflagellates. In: Hallegraeff, G. M., D. M. Anderson \& A. D. Cembella, editors. Manual on harmful marine microalgae, IOC Manuals and Guides No. 33. France: UNESCO. pp. 283-317.

Tubaro, A., S. Sosa, M. Carbonatto, G. Altinier, F. Vita, M. Melato, M. Satake \& T. Yasumoto. 2003. Oral and intraperitoneal acute toxicity studies of yessotoxin and homoyessotoxins in mice. Toxicon 41:783-792.

Utermöhl, H. 1958. Zur Vervollkommnung der quantitativen Phytoplankton-Methodik. Mitt. Int. Vereinigung Theor. Angew. Limnol. 9:1-38.

Van Dolah, F. M. 2000. Marine algal toxins: origins, health effects, and their increased occurrence. Environ. Health Perspect. 108:133-141.

van Egmond, H. P., T. Aune, P. Lassus, G. J. A. Speijers \& M. Waldock. 1993. Paralytic and diarrhoeic shellfish poisons: occurrence in Europe, toxicity, analysis and regulation. J. Nat. Toxins 2:41-82.

Yasumoto, T., M. Murata, Y. Oshima, G. Matsumoto \& J. Clardy. 1984. Diarrhetic shellfish toxin poisoning. In: E. P. Ragelis, editor. Seafood toxins. ACS Symp. series 262. Washington, DC: American Chemical Society. pp. 207-214.

Yasumoto, T., M. Murata, Y. Oshima, M. Sano, G. Matsumoto \& J. Clardy. 1985. Diarrhetic shellfish toxins. Tetrahedron 41:1019-1025. 